\title{
The Impact of Brand Image, Price, and Variety Seeking on Brand Switching Behavior
}

\author{
Firdaus $^{1}$, Budiman ${ }^{2}$ \\ Management, Sekolah Tinggi Ilmu Ekonomi Anindyaguna, Semarang, Indonesia \\ *Correponding Author \\ firdaus@stieanindyaguna.ac.id
}

Received:

17 August 2021
Revised:

13 December 2021
Accepted:

21 December 2021
Published:

31 December 2021

\begin{abstract}
Brand switching behavior is brand switching behavior by consumers or it is interpreted as a consumer's vulnerability to switch to another brand. The purpose of this study to determine the effect of brand image, price and variety seeking to brand switching behavior of the product Slai O'lai with Oreo products. Slai Olai has decreased significantly, whereas it is inversely proportional to Oreo Products which have experienced an increase. This picture shows the changes in consumer behavior makes the transition brand from Slai O'lai of Oreo Product. The population and research sample are residents of Semarang as many as 100 consumers. The sampling technique was carried out using purposive sampling method, namely the sampling technique used by the researcher if the researcher had certain considerations in taking the sample or determining the sample for certain purposes and processing the data using the SPPS version 21 program. The results showed that the fact that the brand shift of biscuit customers was influenced by the brand image, price and the need to look for variations.
\end{abstract}

Keywords : Brand Switching; Brand Image; Price; Finding Variations

\section{INTRODUCTION}

Competition in the increasingly competitive business world provides opportunities for consumers to more freely choose the products they need or want. Because in fact, the increasingly fierce competition in the business world causes more alternative choices for consumers. This is a threat to old companies that are unable to create an innovation for their products. In the science of marketing, a consumer's brand transfer certainly adds to the burden or homework of the company because the brand transfer is a feedback of the company's poor performance or service to consumers, resulting in them making a systematic brand shift, which in turn makes it easy for consumers to switch to brands other. brand switching is a brand shift that consumers use for each time of use (Swa.co.id). Slai O'lai and Oreo are two well-known Sandwich Biscuit Brands in Indonesia. The competition between these two Sandwic h Biscuit Brands is quite tight. Their innovations are awarded every company is different. Although research on the brand switch ing been done by previous investigators, but there are differences in the results.

This Reseach It focuses on two issues namely the phenomenon of business and kesenjagan previous research, such as research that is carried out by Jatmiko (2013) states that the price impact positively on the transfer of the brand but the research that is carried out by Arianto (2013) stating that the price has a negative and significant effect on brand 
shift. Therefore the need for research on the effect of the price of brand switch ing to add variety seeking as an intervening variable. Riani \& Susanto (2015) stated the need to examine the variables that can affect the brand switches, such as brand image, product innovation and price as $m$ ana conducted by Radamuri (2013); Satya (2012). At this time Oreo had experienced a very rapid increase in sales and was able to become a competitor to Slai O'lai. But in the era of these consumers want something that is able to give a variety of products, then from it has many consumers Slai O'lai the switch to Oreo with views of the data consumers Slai O'lai increasingly declined, while Oreo experienced an increase every year. Based on the existing problems, this study raises the theme of the factors that cause consumers to switch brands, the novelty in this study lies in the addition of the variety seeking variable as a variable that is still rarely researched and is associated with brand switching.

Brand switching behavior is brand switching behavior that is carried out by consumers or is also interpreted as the vulnerability of consumers to switch to other brands (Keaveney, 1995). Whereas according to Mazursky et al. (1998), consumers' assessment of brands can arise from various variables, such as consumer experience with previous products and product knowledge. The experience of consumers in using the product creates a commitment to the brand. An experience that creates an unpleasant judgment for a consumer will cause them to make a brand switch. In measuring the switching brands can use multiple indicators including by Susato \& Widyawati (2016) mengatakajn that BS can be measured using following indicators" (1) Willingness to look for variations of other products, (2) Post-purchase dissatisfaction, and (3) the desire to speed up cessation of goods .

According to Kotler (2000), buyers may have different responses to company or brand image. Brand image is the public's perception of the company or its products. Image is influenced by many factors that are beyond the company's control. An effective image will affect three things, namely: first, strengthening the character of the product and the proposed value. Second, convey the character in a different way so that it is not confused with the character of a competitor. Third, it provides emotional strength that is more than just mental images. In order for this to function, images must be conveyed through every available means of communication and brand contact. For example: if "IMB means service" this message must be expressed through symbols, written and audiovisual media, atmosphere (physical space), events (activities), and employee behavior. In measuring the performance of a brand image, several indicators can be used as follows (1) Recognition (recognition ) (2) Reputation (reputation) (3) Affinity (affinity ) Ananda (2010). The image of a brand can make a consumer to switch brands, the lower the image of a product or a brand it will affect consumer behavior toward a brand, like pen e Litian conducted by Sari (2019) says that consumers can make the shift brand through brand image of things these are similar to research conducted by Jatmiko (2013); Mulyani (2019) said that brand image can influence consumer behavior in terms of moving from one brand to another. Based on this, Hypothesis $\mathbf{H 1}$ is published : brand image has an effect on brand switching

Price is the amount of value exchanged by customers who take advantage of owning or using a product or service whose value is determined by the buyer and seller through bargaining, or set by the seller for the same price for all buyers (Umar, 1999). Understanding price Price according to Kotler and Armstrong (2009) is the amount of money 
billed for a product or service. Price, according to Tjiptono (2015), is a monetary unit or other measure that is exchanged in order to obtain ownership rights or use of a good or service. In setting prices, the factors that influence the determination of the price are:

1. Cost becomes lower limit

2. Competitor prices and the price of substitute goods are orientation points that the company needs to consider.

3. Customer assessment of the unique product appearance of the company offering becomes the upper limit of the price.

However, in practice the price is very difficult to measure, therefore an indicator that can describe the performance of the price is needed, according to Kotler \& Armstrong (2008) in measuring prices, using indicators (1) affordability of prices (2) suitability of price with product quality (3) Price competitiveness

In this case, price is able to influence the brand shift of a consumer, as in research conducted by Sari and Dewi (2019); Sari (2019) : Dewantara et al, (2018) who say that price is one of the most crucial determinants of brand shifting as it is known that Indonesian consumers are very unique in responding to existing price differences. Based on previous research, the second hypothesis is formulated, namely H2: Price has a positive effect on brand switching

Variety seeking is a commitment to be conscious to buy the brand another because compelled to get involved or try things new, a sense of want to know the things new, the pleasure of a new, or to address the problem of saturation of the things that the old or usually (Peter and Olson, 2000 in Hanny in Gusti (2010). According to Junaidi and Dharmmesta in Gusti (2010) showed that the need for seeking a variation new to a product as a result of the innovation of products that late . in addition to that, also disclosed that needs searching for variations of this continues to happen again in the market, with many found the product type that is balanced with the products that offer the company. Indicators that can be used as a benchmark to measure the incidence of which variety seeking (1) feel bored (2) Sense wants to see (3) desire to try new things.

In this study, it is necessary to understand the high needs of consumers in looking for product variations that can make consumers take a stand to make a brand shift in accordance with research conducted by Lestari and Sutopo (2011); Reni (2019); Prasetya et al, (2020) said that variety seeking can create consumer behavior so that it can make consumers move brands from one brand to another that they see more attractive . Based on previous research, the third hypothesis $\mathbf{H 3}$ was formulated: variety seeking has an effect on brand switching 


\section{Theoretical Framework}

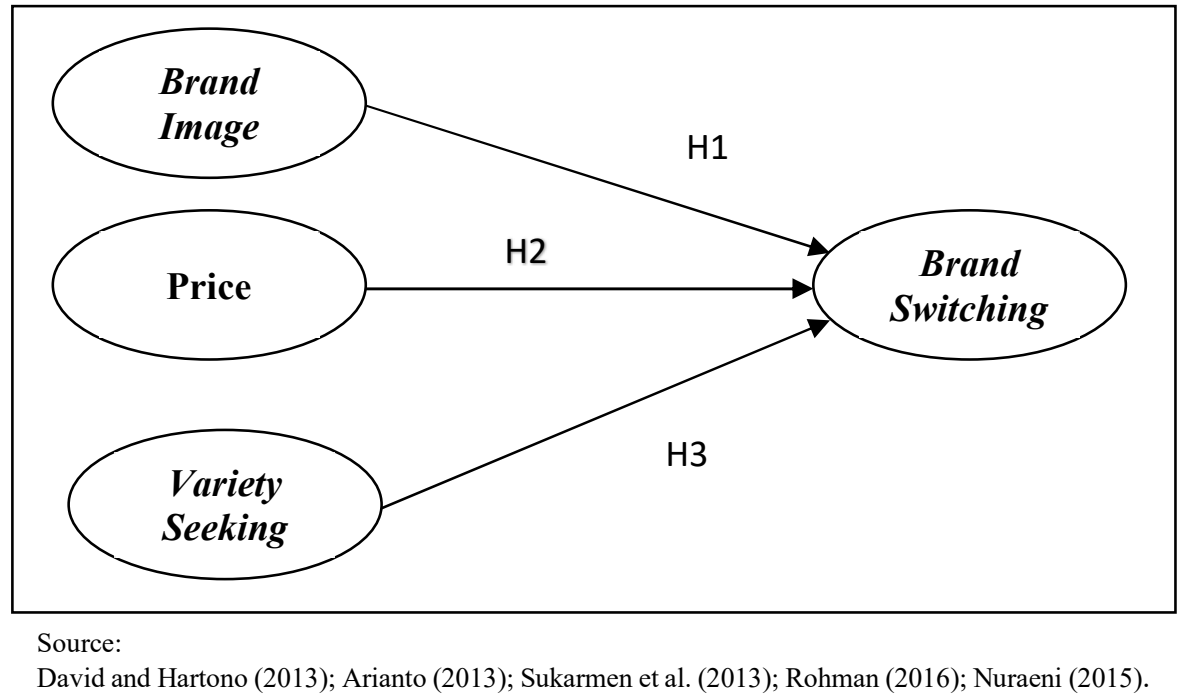

Figure 1. Theoretical Framework

\section{METHOD}

This research is a type of quantitative research, qualitative research is explaining the relationship between variables, testing theory, generalizing the social phenomena under study (Sugiyono, 2015), in which this research uses primary data through a questionnaire with a scale of $1-10$ as the main data.

\section{Population and Sample}

The population is a group or collection of individuals or research objects that have certain standards of previously defined characteristics. Based on these qualities and characteristics, the population can be understood as a group of individuals or objects of observation that at least have one characteristic in common (Cooper \& Emory 1996). The population in this study is the people in the city of Semarang. The sample is part of the population studied. While sampling is a method of collecting data that is not comprehensive, meaning that it does not cover all research objects but only a part of the population, which only includes samples taken from that population (Supranto, 2003). The sampling technique was carried out using purposive sampling method, namely the sampling technique used by the researcher if the researcher had certain considerations in 
taking the sample or determining the sample for a specific purpose. The criteria used in this study are as follows: The customers of Slai O'lai aged more than or equal to 21 years.

\section{Method of collecting data}

This technique is used to collect primary data. The collection of data is done by using one kind of questionnaire, which closed questionnaire, the questionnaire consists of a series of questions used to obtain data on a number of factors that mempengaruhikepuasan customers, that is Service Recovery and Price. The statement in the closed questionnaire uses a numerical scale . Research using numerical scales 1-10 for the following reasons (Husein, 2000):

1. To get universal data

2. some textbooks recommend that data in the "neutral" category should not be used in the analysis as long as the respondent does not provide a reason.

3. To avoid the don't know category

On a numerical scale, the number 1 (one) indicates that the respondent strongly disagrees with the question or statement posed, while the number 10 (ten) indicates that he strongly agrees to obtain interval data and is given a score or value

\section{Research and Analysis Results}

\section{Validity test}

The validity test is used for the relationship between the question items in one variable. Validity testing is done using the Pearson moment formula. Complete validity testing can be seen in the following table.

Table 1. The Results of Validity Test

\begin{tabular}{|c|c|c|c|c|}
\hline No. & Indicator & $\mathrm{r}$ count & $\mathrm{r}$ table & Information \\
\hline 1. & $\begin{array}{l}\text { Brand image } \\
\text { Indicator } 1 \\
\text { Indicator } 2 \\
\text { Indicator } 3\end{array}$ & $\begin{array}{l}0.812 \\
0.802 \\
0.781\end{array}$ & 0.1654 & $\begin{array}{l}\text { Valid } \\
\text { Valid } \\
\text { Valid }\end{array}$ \\
\hline 2. & $\begin{array}{l}\text { Price } \\
\text { Indicator } 1 \\
\text { Indicator } 2 \\
\text { Indicator } 3\end{array}$ & $\begin{array}{l}0.693 \\
0.732 \\
0.679\end{array}$ & 0.1654 & $\begin{array}{l}\text { Valid } \\
\text { Valid } \\
\text { Valid }\end{array}$ \\
\hline 3. & $\begin{array}{l}\text { Needs looking for } \\
\text { variety } \\
\text { Indicator } 1 \\
\text { Indicator } 2 \\
\text { Indicator } 3 \\
\end{array}$ & $\begin{array}{l}0.632 \\
0.684 \\
0.758\end{array}$ & 0.1654 & $\begin{array}{l}\text { Valid } \\
\text { Valid } \\
\text { Valid }\end{array}$ \\
\hline 4. & $\begin{array}{l}\text { Brand switching } \\
\text { Indicator } 1 \\
\text { Indicator } 2 \\
\text { Indicator } 3\end{array}$ & $\begin{array}{l}0.686 \\
0.751 \\
0.733\end{array}$ & 0.1654 & $\begin{array}{l}\text { Valid } \\
\text { Valid } \\
\text { Valid }\end{array}$ \\
\hline
\end{tabular}


Based on the validity test carried out through the SPSS program, it can be said that all indicators used in this study are validly distributed because the calculated $t$ value is greater than the $t$ table value, so it fulfills the validity of the data.

\section{Reliability Test}

Reliability test is a test of the consistency of the respondent's answer, is it consistent over time. The reliability test results between brand image, price, the need to look for variations, and brand transfer can be seen in the following table

Table 2. The Result of Reliability Test

\begin{tabular}{llll}
\hline & & The value of $\mathrm{r}$ & \\
No. & Indicator & Alpha & Information \\
\hline 1. & Brand image & 0.897 & Reliable \\
2. & Price & 0.838 & Reliable \\
3. & Needs looking for variety & 0.830 & Reliable \\
4. & Brand transfer & 0.851 & Reliable
\end{tabular}

Based on the reliability test carried out, data shows that the Cronbach alpha value of each variable is above 0.6 , which means that all variables are said to be reliable because they meet the requirements.

\section{Classic assumption test}

Normality test

Whether the data on the dependent variable is normal or not is done by looking at the normal plot graph. If the normal distribution of data, then the spread of the plot will be along the line of $45^{\circ}$. From the normal plot graph (appendix) it can be seen that the plot spread is along the 450 line so it can be concluded that the data is normally distributed. The information above can be described as follows:

Based on the scater plot image, it can be seen that the points do not spread and the points converge around the diagonal line, so it can be said that the data is normally distributed. 


\section{Multicollinearity Test}

Basically, a multiple regression equation model using two or more independent variables, almost always there is multiple collinearity. The multicollinearity test is intended to determine the perfect relationship between the independent variables in the regression model. If multicollinearity occurs, the collinear independent variable can be eliminated. To determine the presence or absence of multicollinearity, according to calculations carried out by the SPSS program, it can be seen by observing that the value of VIF $>10$ and Tolerance $<0.1$. Referring to the two opinions above, based on the results of the research that has been carried out, the following values can be obtained:

Table 3. The Result of Multicollinearity Test

\begin{tabular}{|ll|l|l|}
\hline \multirow{2}{*}{ Model } & \multicolumn{2}{|l|}{ Collinearity Statistics } \\
\cline { 3 - 4 } 1 & Brand_image & Tolerance & VIF \\
\hline & Price & .743 & 1,471 \\
& Variety & .899 & 1,346 \\
&
\end{tabular}

a. Dependent Variable: brand transfer

\section{Heteroscedasticity Test}

Heteroscedasticity occurs when there is no standard deviation in the value of the dependent variable in each independent variable. Detect by looking at the presence or absence of certain patterns on the chart.



Figure 1. The Result of Heteroscedasticity Test

Based on the graph of the research results above, the existing detection is spread, and does not form a certain pattern, so there is no heteroscedasticity.

\section{Multiple Regression Analysis}

Based on the calculation of multiple regressions between brand image $\left(\mathrm{X}_{1}\right)$, price $\left(\mathrm{X}_{2}\right)$, and the need to look for variations $\left(\mathrm{X}_{3}\right)$ on brand transfer $(\mathrm{Y})$ with the help of the SPSS program in the calculation process, the following results can be obtained. 
Coefficients

Table 4. Multiple Regression

\begin{tabular}{|ll|l|l|l|l|l|}
\hline \multirow{2}{*}{ Model } & \multicolumn{3}{|l|}{ Unstandardized Coefficients } & $\begin{array}{l}\text { Standardized } \\
\text { Coefficients }\end{array}$ & & \\
\cline { 2 - 5 } & & $\mathrm{B}$ & Std. Error & Beta & $\mathrm{T}$ & \multirow{2}{*}{ Sig. } \\
\hline 1 & (Constant) & 2,453 & 2,118 & & 1,158 & .250 \\
& Brand_image & .250 & .082 & .285 & 3,062 & .003 \\
& Price & .205 & .085 & .214 & 2,401 & .018 \\
& Variety & .397 & .082 & .392 & 4,846 & .000 \\
\hline
\end{tabular}

a. Dependent Variable: brand switching

\section{RESULT AND DISCUSSION}

This study wants to confirm that in the context of brand switching carried out by consumers it can be influenced by the three variables proposed in this study, such as the brand image variable which has a significant value of $0.003<0.05$, which means the brand image owned by the company at any time. can change consumer decisions in choosing a product they want, this is also in line with research conducted by Sari (2019); Jatmiko (2013); Mulyani (2019) said that brand image can influence consumer behavior in terms of moving from one brand to another.

The same thing is shown by the price variable which in this study has a significant level of $0.018<0.05$, which means that price is an important element that is often the focus of consumers, therefore the price strategy must be considered properly by companies at least the price determined by a product follows the existing market price for the same product and the same quality, this is in accordance with research conducted by Sari and Dewi (2019); Sari (2019): Dewantara et al, (2018) who say that price is one of the most crucial determinants of brand shifting as it is known that Indonesian consumers are very unique in responding to existing price differences.

Another variable with the highest level of significance in influencing consumer behavior in brand switching is the need to look for variations or new products because we know that consumers are very easily bored with a product they always consume, therefore it is also necessary. companies think about the tastes and desires of consumers so that consumers do not run to other companies because this can lead to brand shifting if not handled properly by the company, similar to research conducted by Lestari and Sutopo (2011); Reni (2019); Prasetya et al, (2020) said that variety seeking can create consumer behavior so that it can make consumers move brands from one brand to another that they see more attractive. In the end, these three variables must be one of the main focuses for companies to be able to maintain their customers, considering that the business world is very dynamic as well as the wants and needs of consumers which are very volatile.

In this study, the indicators of each variable also contribute to determining a consumer to make a brand switch, for example for the indicators of price affordability, 
price conformity with product quality and price competitiveness in the price variable, these indicators can be a strong trigger when the price of a product cannot be reached by consumers or the competitiveness and price of the product is not in accordance with the quality of the product, of course consumers will switch to other product brands or in this study consumers will switch brands from S'Lai Olai to Oreo.

In addition to indicators of the price variable, there are indicators of the desire of consumers to look for other product variations as well as post-purchase dissatisfaction felt by consumers (Firdaus, 2019). In addition to the emergence of boredom, curiosity about other products and the desire to try other products, this can be a strong reason for a consumer to switch brands from one brand to another. As happened in this study, Slai Olai consumers moved to Oreo due to the curiosity and boredom of these consumers, so they decided to switch brands.

\section{Model Eligibility Research}

Table 5. ANOVA Result

ANOVA ${ }^{\circ}$

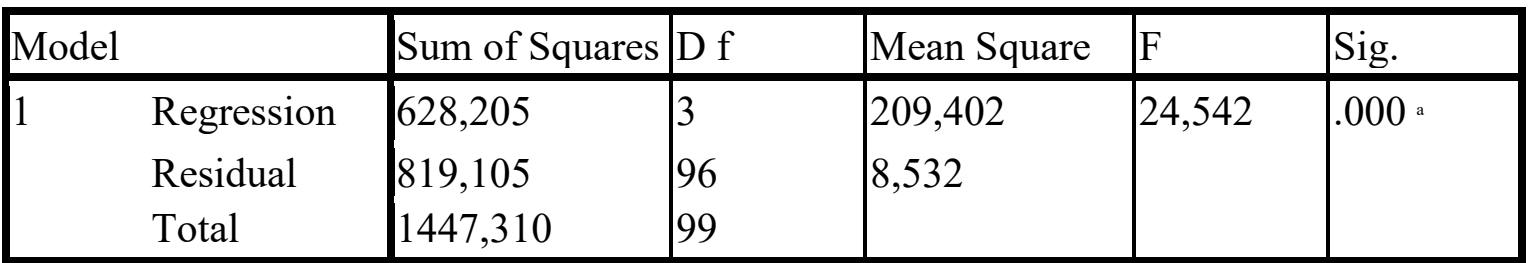

In this study, it focuses on the calculated f value and the significant value of the existing table, it can be concluded that the model proposed in this study is worthy of research.

To find out the value of the coefficient of determination indicated by the value of Adjusted $R$ Square. This is the result of the coefficient of determination

Table 6. Model Summary

Model Summary
\begin{tabular}{|l|l|l|l|l|}
\hline Model & $\mathrm{R}$ & R Square & $\begin{array}{l}\text { Adjusted } \\
\text { Square }\end{array}$ & $\begin{array}{l}\text { R } \\
\text { Std. Error of the } \\
\text { Estimate }\end{array}$ \\
\hline 1 & .659 a & .434 & .416 & 2.92102 \\
\hline
\end{tabular}

a. Predictors: (Constant), product attributes, prices, promotions

Based on Table 6, it can be seen that the value of Adjusted $R$ Square is 0.416 which indicates that between brand image, price, and the need to look for variations are able to explain together the brand shift of $41,60 \%$, while the rest is influenced by other variables not examined.

\section{CONCLUSION}

This research is an attempt to answer research problems as mentioned in this study, in which the research problem in this study is why consumers switch brands easily? what factors influence the brand shift rate of biscuit consumers. From the research has 
answered these research problems which significantly produces three things that influence brand switching, ie $\mathrm{d}$ ari research results indicated that turned out to transfer customer brand crackers are influenced by brand image, pricing as well as the need to find variations. This means that by improving the quality of the brand image, increasing price competitiveness and continuing to innovate in the need to find variations, other prepaid products customers can be expected to switch brands to Oreo products from Slay Olay products. It thats company can do in relation to these findings, among others: the Company to suitability price with the quality expected by the consumer. Companies also need to pay attention to price compatibility with product features that have been promised in advertisements and promotions. Companies need to pay attention to competitor prices, and maintain Slai Olai products to remain competitive in the eyes of consumers by making product innovations that are getting better and adjusting to consumer preferences in Indonesian (Firdaus, 2020).

In this study, to address the phenomenon of brand switching, in this case, Slai Olai needs to make product innovations that are different from the others, such as bringing up Slay Olay products with chocolate variants, because so far, chocolate variants have not been introduced, while people who love snacks, really like the taste of chocolate and other flavors favored by Indonesian consumers.

In addition, competitive prices need to be highlighted because so far, the price of Slay Olai products is relatively cheaper than Oreo, consumers should not switch brands if the price offered is cheaper, but under certain conditions, consumers feel prouder when using or consuming food. which is more expensive, besides that in this case, the variant of a product is very important for the company to do, considering the level of consumer saturation or boredom is quite high, therefore new breakthroughs are needed, in order to keep consumers or Slay Olai customers.

\section{Research Limitations}

From the results of this thesis discussion, some of the limitations of the study can be conveyed as follows: From the results of data processing, it can be seen that the value of Adjusted $R$ Square is 0.416 which indicates that the brand image, price, and the need to look for variations can explain together the brand shift. amounted to $41,60 \%$. Thus, there are actually other variables that were not investigated which may have influenced the shift in prepaid card brands. If you look at a response rate that is less than $50 \%$, it can be said that the findings of this study cannot be said to be a picture of the total opinion of Semarang students as a whole.

\section{Research Agenda}

Further research can be done by looking at the limitations in this research is the need to incorporate other variables that have not been examined in this study as a variable relationship quality (Firdaus \& Massy, 2020). Future research needs to increase the level of response rate by conducting direct interviews. In order for research Better yet, the next researcher is expected to use longitudinal research, which is to take samples regularly, not just once in distributing questionnaires but maybe up to three times, so that in data collection, researchers really get real data from consumers (Ruspini, 2000; Taylor et.al., 2000). 


\section{REFERENCES}

Aeni, N. (2014). Analysis of Factors Affecting Brand Switching Behavior on XL Prepaid Cards (Study on consumers of Pandumedia Reload Service Singosari-Malang). BUSINESS SKETCH 1 (1).

Arianto, A.B. (2013). The Influence of Product Attributes, Prices, Needs to Seek Variations and Consumer Dissatisfaction with the Decision to Change Brands from Samsung Galaxy Series in Malang City. Journal of Management Applications-Journal of Applied Management 11 (2): 294-305

Cooper, R. D., \& Emory, W. C. (1996). Business research methods, 5th edition, volume 1, Erlangga.

Dewantara, S ., Mursito, B ., \& Kustiyah, E . (2018). Analysis of Dissatisfaction Factors, Product Features, Prices, and Word Of Mouth Against Brand Switching on Oppo Smartphone Products. Journal of Economics and Entrepreneurship, 18 (1).

Tjiptono, F. (2015). Marketing Strategy; 4th Edition. Andi Offset.

Firdaus, F. (2019). Analisis Kepuasan Nasabah Melalui Keprcayaan Nasabah, Kualitas Layanan Dan Kualitas Produk (Studi Kasus Pada Kospin Jasa Cabang Weleri). Anindyaguna Ekonobisnis: Jurnal Ekonomi dan Bisnis STIE Anindyaguna, 1(2). https://doi.org/10.0593/jae.v1i1.4

Firdaus, F. (2020). Marketing Performance Based on Product Innovativeness and Islamic Differentiation Advantage. Li Falah: Journal of Islamic Economics and Business Studies, $5(1), 42-66$.

Firdaus, F. (2020). Strategy Creating Positive Word of Mouth Based On Relationship Quality. Jbti: Journal of Business: Theory and Implementation, 11 (3).

Ghozali, M. (2015). The Effect of Service Quality and Price on Customer Satisfaction on Expeditions in Surabaya. Journal of Management Science \& Research 3 (3).

Harianto, D. (2013). Analysis of the influence of service quality, brand image, and atmosphere on consumer loyalty with customer satisfaction as an intervening variable of consumers at Deja-vu shops in Surabaya. Journal of Marketing Strategy 1 (1)

Herliza, R., \& Saputri, M. E. (2016). Pengaruh Brand Image Terhadap Kepuasan Pelanggan (studi Pada Zara Di Mall Pvj Bandung). eProceedings of Management, 3(2).

Husein, U. (2000). Marketing Research and Consumer Assessment. PT Gramedia.

Supranto, J. (2003).Legal and Statistical Research Methods. PT. Rineka Cipta.

Jatmiko, M. R. (2013). Analysis of Effect of Promotion, Price, and Product Attributes Against Displacement Brand (Brand Switching) Card Mobile In STIE Totalwin Semarang. Doctoral Dissertation. Universitas Diponegoro.

Kotler. Armstrong (2009). Indonesian Edition Marketing Principles. Jakarta. Erlangga

Lestari , D . V ., \& Sutopo, S . (2011). Consumer dissatisfaction Effect Analysis, Requirements for Variation, Consumer Engagement, Price And Fascination Against Competitor Brand Switching Behavior (Case Study on Phone Users Mobile Sony Ericsson in Semarang) Doctoral Dissertation, University of Diponegoro. 
Muliyani, D. (2019). Effect of Product Quality and Brand Image of Brand Switching And Brand Loyalty ( Studies in Student - student of the Department of Mechanical Machining SMK Negeri 2 Depok, Sleman, Yogyakarta Ever Make Switching Brands Smartphone Other All Brand Xiaomi). Doctoral Dissertation. University of National Development Veteran Yogyakarta.

Prasetya, A . Y ., Winalti , S ., \& Kiswoyo , K . (2020, November ). Analysis of Seeking Variety, Product Attributes and Price on Brand Switching from Conventional Taxis to Online . In Proceedings of the National Seminar \& Call For Paper STIE AAS (Pp. 001-019).

Prayogo, KD and F. Andreani (2014). The influence of brand image on customer satisfaction with perceived value as an intermediary variable in TX Travel Surabaya. Journal of Hospitality and Service Management 2 (2): 435-449

Pusparani, PAY and NM Rastini (2014). The Effect of Product Quality and Brand Image on Customer Satisfaction and Customer Loyalty of Canon Digital Single Lens Reflex (DSLR) Cameras in Denpasar City. Udayana University Management E-Journal 3 (5)

Reni, P . S . (2019). The Influence of Price, Product Quality, Promotion, and Variety Seeking on Brand Switching (Case Study of Economic Education Students of STKIP PGRI West Sumatra ). Doctoral Dissertation, STKIP PGRI West Sumatra ).

Riani, D., \& Soesanto (2015). The Influence of Celebrity Endorser and Word of Mouth on the Interest in Brand Switching with Perceived Value as Mediation (Studies on Consumers of Wardah Cosmetics Products), Faculty of Economics and Business

Ruspini, E. (2005). Longitudinal Research in the Social Sciences. Social Research Update, 28. Http://Www.Soc.Surrey.Ac.Uk/Search/Search. Htm. Retrieved January 2, 2005.

Sari, D . M . F . P ., \& Goddess, D . A . P . Y . T . (2019). Smartphone Brand Switching (Xiomi and Oppo) on Erafone Megastore in Denpasar City. Scientific Journal of Management and Business , 4 (2), 89-96.

Sari, R . U . L . (2019). The Effect of Product Quality, Price, and Brand Image on Brand Switching (Case Study of Harum Pucuk Tea). Doctoral Dissertation. Mercu Buana University Jakarta.

Sugiyono. (2015). Combination Research Methods (Mix Methods). Alfabeta

Sukarmen, P., Sularso, R. A., \& Wulandri, D. (2013). Analisis Pengaruh Inovasi Produk Terhadap Kepuasan Konsumen Dengan Keunggulan Bersaing Sebagai Variabel Intervening Pada Produk Gula Pasir Sebelas (Gupalas) Pabrik Gula Semboro Ptp Nusantara Xi (Persero). Jurnal Ekonomi Akuntansi Dan Manajemen, 12(2). 